ELORE (ISSN 1456-3010), vol. 15 - 2/2008.

Julkaisija: Suomen Kansantietouden Tutkijain Seura ry. [http://www.elore.fi/arkisto/2_08/hon2_08.pdf]

\title{
KOLUMNEN
}

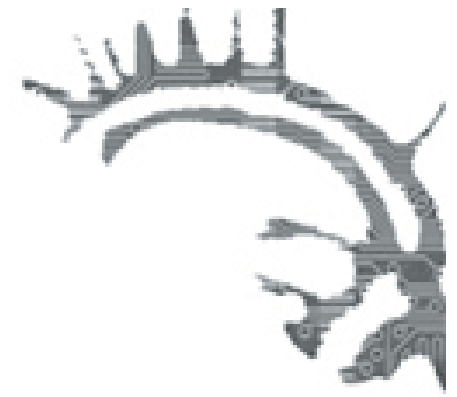

\section{TillbaKablickar PÅ RELIGIONSVETENSKaPENS UTVECKLING VID ÅBo AKADEMI OCH UTMANINGAR INOM ÄMNET I DAG}

\section{Nils G. Holm}

Som vi vet är religionsvetenskapen en relativt ny vetenskapsgren. Den växte fram $\mathrm{i}$ mitten och slutet av 1800-talet i flera av Europas länder. I Finland är denna vetenskapsgren tämligen ny i den form vi har idag. Den sträcker sig inte ens över hela min levnad.

I slutet av 1950-talet grundades vid Åbo Akademi Donnerska institutet för religionshistorisk och kulturhistorisk forskning genom personlig donation av Olly och Uno Donner. Tanken på att i anslutning till institutet grunda en professur i religionshistoria slog snabbt rot. Redan 1959 fattades beslut om en sådan professur och den förlades till Humanistiska fakulteten. År 1960

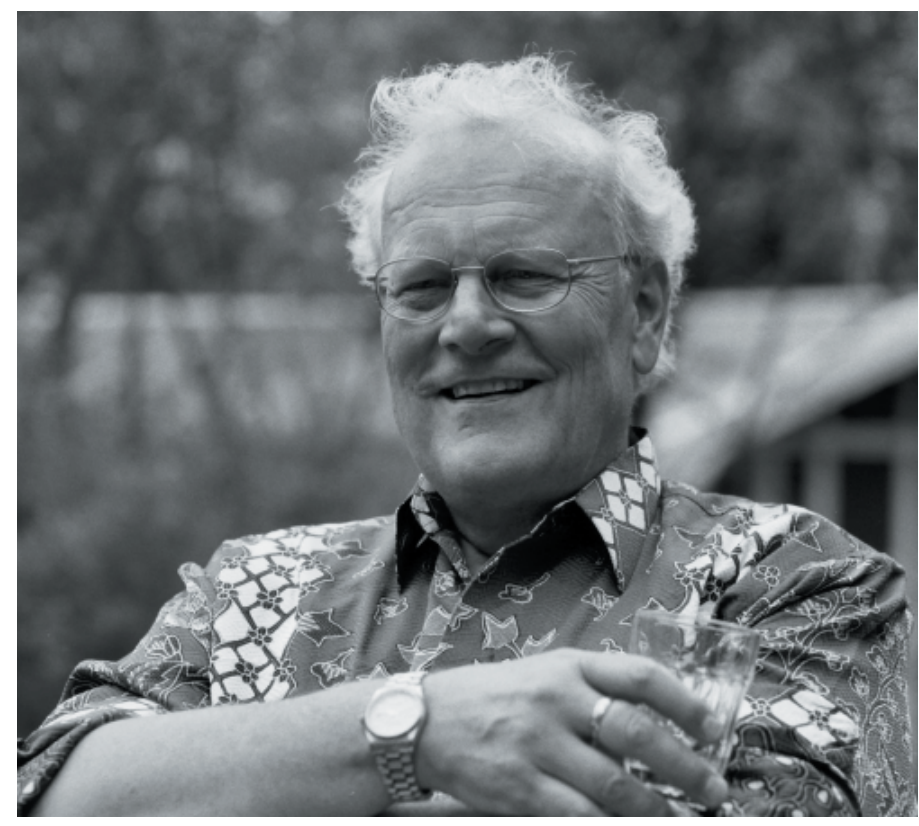

Foto Gabi Limbach. kallades docenten vid Uppsala universitet Helmer Ringgren till första innehavare av professuren, och han utnämndes i slutet av 1961. Undervisningen påbörjades hösten 1962, samma år som jag vidtog mina studier vid Åbo Akademi. Som teologie studerande deltog jag aktivt i hans föreläsningar och fascinerades storligen av de vida perspektiven på religion som han gav.

Ämnesbeskrivningen för professuren var formulerad så att professorn skulle undervisa i religionshistoria, religionsfenomenologi, religionspsykologi och religions- 


\section{TILLBAKABLICKAR PÅ RELIGIONSVETENSKAPENS UTVECKLING}

sociologi. Ännu när jag för knappt trettio år sedan sökte och erhöll professuren gällde denna bestämning. Idag uppfattas bestämningen alltför bred och omöjlig för en enda innehavare att täcka. Det kan tilläggas att professurens benämning ändrats vid Åbo Akademi år 1994 från religionshistoria till religionsvetenskap. Ämnet är förlagt huvudsakligen till Humanistiska fakulteten men finns också företrätt vid Teologiska fakulteten varför personalen i praktiken sköter ämnet vid två fakulteter. Stora ändringar har skett inom hela vårt ämnesområde och jag skall kort beröra några punkter som jag tycker är viktiga att lyfta fram inför framtida forskningar i religionsvetenskap.

Ämnets identitet baserar sig vid Åbo Akademi i hög grad på den utformning motsvarande ämne haft och har i Sverige, framför allt vid Uppsala universitet. Det innebär att tonvikten ligger på undervisning och forskning kring de stora religionerna i världen. Denna tradition uppfattar vi som viktig att fortsätta med. Den utgör en kärna $i$ vår vetenskap som vi inte på något vis vill lämna till företrädare för andra ämnen. Vi har nämligen ibland sett en tendens hos vissa inte alltid ens närstående ämnen att på något vis ta över religionsforskningens uppgifter. Det har att göra med det faktum att religionen som företeelse i världen på ett helt annat sätt än bara för trettio år sedan lyfts fram i ljuset och blivit behandlad i massmediala sammanhang. Under min studietid på 1960- och 70-talen uppfattades religionen ofta som antikverad och något som skulle försvinna. Men sedan kom revolutionen i Iran i slutet av 1970-talet och världens ögon öppnades på ett helt annat sätt än tidigare för religionen som en politisk och social faktor. Andra händelser i världspolitiken och på det globala planet har sedan ytterligare förstärkt det allmänna intresset för religionen som kulturfenomen och som socialt och psykologiskt drivmedel. Jag tänker då inte minst på de så kallade nya religiösa rörelserna som nådde oss på 1970-talet, senare även Kuwaitkriget, Rushdie-incidenten, motsättningarna mellan hinduer och muslimer i Indien, Irakkriget och mycket mer.

Allt det här gör att kraven på vår vetenskap har höjts kraftigt under senare år. När jag för knappt trettio år sedan blev professor i ämnet var globaliseringen inte på långt när så utvecklad som den är idag - inte i vårt land i varje fall. Till mina grunduppgifter som företrädare för ämnet hörde vid den tiden i stor utsträckning att ge information om de grundläggande förhållandena inom världens religioner. Hos befolkningen i allmänhet $\mathrm{i}$ vårt land var kännedomen om främmande kulturer och religioner svag, för att inte säga mycket svag. Det var därför viktigt med introduktion på grundläggande nivå om världens religioner. Idag är situationen delvis en annan. Vi får idag i massmedierna på ett helt annat sätt än tidigare information om andra religioner och kulturer. I nyhetssändningar i Finland hör man idag till exempel om skaror som är på pilgrimsresa till Kerbala, den plats där al-Husein stupade år 680 . En sådan information i massmedierna bara för kanske tjugo år sedan hade varit $\mathrm{i}$ det närmaste otänkbar. Till detta kan läggas ytterligare att man reser i en sådan omfattning som man aldrig tidigare gjort $\mathrm{i}$ historien. Man möter personligen andra kulturer och religioner i främmande länder. Även om man sällan kommer religionerna nära under sådana resor, väcks ändå ett intresse för de andra kulturerna. 


\section{NiLS G. HoLm}

Ytterligare en sak som förändrat situationen för oss är invandringen. Idag har vi $i$ vårt land och i övriga delar av Norden och Europa grupper av människor med annan tro och livsuppfattning än vad som traditionellt förekommit hos oss. Detta gör att vår forskning och undervisning $i$ religionsvetenskap på ett helt annat sätt än tidigare måste vara specialiserad och fördjupad.

Att inom vårt ämne bibehålla bredden samtidigt som en kraftig fördjupning måste ske är inte alltid lätt. Fördjupning i språk som arabiska, sanskrit, pali, kinesiska och andra viktiga språk är inte möjlig till exempel vid Åbo Akademi, vilket gör att en specialisering inom religionsforskningen kan te sig lite svår. Men skyldigheten att besitta så fördjupade kunskaper som möjligt inom vår vetenskap för att tillfredställa allmänhetens och samhällets behov kvarstår. Det finns tillräckligt med uppgifter inom religionsforskningen trots att vi inte kan erbjuda den filologiska fördjupningen på så många områden som vi skulle önska.

En annan viktig utmaning som sammanhänger med den jag redan omtalat är den religionspedagogiska. Vårt ämne bidrar kännbart till utbildningen av religionslärare och livsåskådningslärare. Ända från början av min professorstid har jag uppfattat denna uppgift som synnerligen väsentlig. Det har också varit nödvändigt eftersom få andra skött den saken. Därför har vi vid Åbo Akademi engagerat oss i flera religionspedagogiska projekt och gör det fortfarande. Att dra upp riktlinjer för hur undervisningen $i$ andra religioner och kulturer skall gå till $i$ våra skolor på olika nivåer är viktigt, och det är ingalunda självklart hur dessa anvisningar ska se ut. Det behövs både teoretisk och praktisk insikt i hur man gör då en grundläggande undervisning alltid innebär ett slags förenkling och renodling av viss information. Allt detta bör göras så att inte fördomar uppstår och hinder för en vidare utveckling av ungdomarnas världssyn uppkommer. Till all lycka finns idag internationella organisationer och konferenser där dessa frågor diskuteras och där man får råd och tips för hur man skall utforma en ändamålsenlig pedagogik.

En tredje uppgift som jag här vill lyfta fram är metoderna inom vår vetenskap. Metoder alltifrån enkla referat och tolkningar till fältforskning och experiment kan komma ifråga. Allt detta fordrar utbildning och gott handalag. Normalt innebär den akademiska utbildningen att man lär sig sådana metoder och kan tillämpa dem i forskningssammanhang. I framtiden tror jag dock att en metodologisk breddning är en nödvändighet för våra forskare. Det räcker inte enbart med att man behärskar vissa former av metoder. Jag har beklagat att de kvantitativa och statistiska metoderna inte rymts med i metodundervisningen hos oss. Smärre introduktioner till dessa har jag försökt ge under seminariernas gång men någon fördjupning har det inte blivit fråga om. Studenter med personligt intresse för sådana metoder och med uppgifter som ligger i linje därmed, har i rätt hög grad självständigt lärt sig hantverket. Att man i varje fall i viss mån bör känna till metoder av detta slag står klart eftersom jag sett många bevis på att de som inte behärskar dem har stora fördomar om deras användbarhet. Det finns en tydlig motsättning mellan dem som önskar arbeta enbart med kvalitativa metoder och dem som arbetar med kvantitativa. Denna motsättning tycker jag är beklaglig och jag har i görligaste mån försökt överbrygga den. 


\section{TILLBAKABLICKAR P̊ RELIGIONSVETENSKAPENS UTVECKLING}

Så kommer vi in på de teoretiska infallsvinklarna. Det förefaller vara så att vissa teorier under en del perioder blir populära och lyfts fram som nya och "allena saliggörande". Jag vill dock kraftigt avråda ifrån en ensidighet i de teoretiska frågeställningarna. En pluralism och öppenhet på detta område är något jag vill förespråka. Bilden av religionens former och funktioner blir aldrig fullständig men genom en strävan efter teoretisk variationsrikedom, tror jag vi får en mer fullständig bild av vad det här är fråga om.

Inom mitt eget specialiseringsområde, religionspsykologin, har teoretiska skolbildningar brutit sig mot varandra under drygt hundra år. Det som var gängse för knappt ett sekel sedan, det vill säga att se religionen som ett resultat av evolutionen, förkastades strax efter andra världskriget, och de historiska och socialkonstruktivistiska teorierna fick dominerande ställning. Under senare år har däremot en nyare form av evolutionism inom vår vetenskap ryckt fram. Nu är det religionens grund i kognitionsutvecklingen som fått framgång. En fara lurar dock här bakom hörnet på samma sätt som för 70-80 år sedan, det vill säga den att människor och kulturer rangordnas i enlighet med kognitiv förmåga. Ett kulturevolutionistiskt synsätt kan leda till utklassning och förnedring för vissa grupper. En sådan utveckling måste vi se upp med och kraftigt motarbeta.

Inom religionspsykologin, och inom hela vår vetenskap hoppas jag, är det en självklarhet att religionen bör ses som en produkt av den förmåga och psykiska kapacitet människan har. All religion är i den bemärkelsen helt mänsklig, för att inte säga fysisk eller kroppslig. Psyket baserar sig på de biologiska och fysiska processerna i vår kropp. Genom historiens gång har traditioner, kulturer och religioner formats utgående från människors psykiska förmåga till kommunikation och formalisering. Att studera dessa och se deras historiska utveckling, deras olika formationer i olika tider och på olika platser och hur de påverkat och påverkar varandra är viktiga uppgifter inom vår vetenskap. Det är fråga om det som jag valt att kalla för det yttre existensrummet.

Dessutom måste vi studera den enskilda människan och hur hon tar emot allt detta och växer in i det. Den socialkonstruktivistiska infallsvinkeln blir då väsentlig samtidigt som man måste se till människans inre dynamiska processer. Då kommer även sådant som ofta går under beteckningen djuppsykologi att behöva beaktas.

Allt detta har jag kortfattat och översiktligt beskrivit i det som jag kallar en integrerad rollteori. Jag räknar alltså med ett yttre existensrum där kulturerna och religionerna tillhandahåller ett norm- och rollsystem som vi alla möter under uppväxt och fortsatt levnad. Detta system konfronteras sedan med det inre existensrummet, det som vi var och en bär med oss i vårt minne och hela vår psykiska apparat. Genom positiva möten mellan dessa existensrum får vi en upplevelsevärld som är unik för varje enskild individ och som gör kulturens och religionens symbolsystem meningsfulla för oss. Ibland händer det dock att negativa känsloreaktioner uppkommer och då kan religionens symbolspråk upplevas antikverat, felaktigt och rent av kränkande. Att fortgående studera den enskilda individen i relation till de stora religionerna och kulturerna i allmänhet, är en uppgift som aldrig kan bli uttömd. 


\section{NiLs G. Holm}

Jag önskar att vår vetenskap i framtiden skall se sin uppgift i skärningspunkten mellan de stora socialt givna religionsformationerna och den enskilda individen som skall växa in i kulturerna och forma sin egen erfarenhetspalett. Jag menar således att vi bör behålla vårt synfält inom forskningen så att vi å ena sidan studerar den kollektiva och socialt tillhandahållna religionen och, å den andra, individen och dennas möte med kulturer och religioner i samhälle, skola och universitet. Det är en uppgift som vi aldrig blir färdiga med. Den har vördnadsvärda anor och rör vid människors och kulturers allra innersta väsen. Det är en uppgift som jag med varm hand överlämnar till kommande generationer av lärare och forskare inom ämnesområdet.

\section{REFERENSER}

HOLM, NILS G. 1995: Religious Symbols and Role Taking. - Holm, Nils G. \& Belzen, J. A. (eds.), Sundén's Role Theory. An Impetus to Contemporary Psychology of Religion. Religionsvetenskapliga skrifter $\mathrm{nr} 27$. Åbo: Åbo Akademi.

- 1997: Människans symboliska verklighetsbygge. En psykofenomenologisk studie. Religionsvetenskliga skrifter nr 40. Åbo: Åbo Akademi.

- 2002: Att förstå religiösa erfarenheter. - Gothóni, René (red.), Att förstå inom bumaniora. Helsingfors: Finska Vetenskaps-Societeten.

Nils G. Holm är professor emeritus i religionsvetenskap vid Åbo Akademi. 